KONSTANTĪNS BEN̦KOVSKIS

LUDMILA FADEJEVA

KRISTA KALNBĒRZIN,A

\title{
PRICE SETTING BEHAVIOUR IN LATVIA: ECONOMETRIC EVIDENCE FROM CPI MICRO DATA
}




\section{CONTENTS}

Abstract 2

Introduction 3

1 Descriptive Evidence on Price Setting Behaviour in Latvia 4

1.1 Description of the database 4

1.2 Main characteristics of consumer price setting mechanism 5

2 Theoretical and Empirical Models of Price Setting Mechanism 10

2.1 Time-dependent and state-dependent pricing models $\quad 10$

2.2 Logit model of probability of price change $\quad 10$

2.3 Factors describing probability of price change 12

3 Results of the Model 16

3.1 Explaining probability of price change 16

3.2 Distinguishing between price increases and decreases 19

3.3 Explaining probability of sales $\quad 23$

Conclusions 25

$\begin{array}{ll}\text { Appendix } & 27\end{array}$

Bibliography 33

CSB Central Statistical Bureau of Latvia

EU European Union

VAT Value Added Tax 


\section{ABSTRACT}

This paper discovers the driving forces behind firms' decisions to adjust prices by using various panel logit models, which explain the probability of observing price change by a broad set of exogenous variables. The results of the models show that the consumer price formation in Latvia is a combination of both state-dependent and time-dependent behaviour. On the one hand, frequency of price changes depends on inflation, demand conditions, and the size of last price changes. On the other hand, we observe some elements of time-dependent price setting, e.g. price truncation and strong seasonal pattern. We also find several important differences in the price setting behaviour for cases of price increases and decreases. The fact that frequency of price changes in Latvia depends on inflation as well as demand and supply conditions could be seen as a prerequisite for faster price adjustment process in the event of distortions in the economy. In the case of economic imbalances, statedependent price formation changes flexibility of prices and ensures a faster adjustment process towards equilibrium.

Keywords: price setting behaviour, Latvia's consumer prices, frequency of price change, sales, time-dependent pricing, state-dependent pricing, panel logit model

JEL codes: C23, D40, E31

The views expressed in this publication are those of the authors, who are employees of the Monetary Policy Department of the Bank of Latvia. The authors assume responsibility for any errors and omissions. 


\section{INTRODUCTION}

The question of price stickiness remains one of the most important in macroeconomics, as price (and wage) flexibility determines how long the economic adjustment process after a shock is. High price flexibility means a fast price-wage adjustment mechanism and ensures that consequences of various real and nominal shocks will not last long. Therefore, a good understanding of price setting behaviour is crucial for the economic analysis, forecasting and policy making. Moreover, empirical evidence on price setting is also important for building macro models with adequate micro data foundations.

The analysis of micro data, e.g. surveys on prices of individual products from individual outlets, can provide a better understanding of price change frequency and size. The advantage of this approach is twofold: first, it allows for studying the price setting mechanism directly; second, it provides not only general information on aggregate price settings, but also the details at sector and individual product level.

The most recent descriptive study on the degree of nominal rigidity of consumer prices in Latvia has been conducted by Benkovskis et al. (2010) using the micro data database on consumer prices provided by the Central Statistical Bureau of Latvia (CSB). The main finding is that during 2003-2009 Latvia's consumer prices were flexible. The average duration of a price spell was 3.5 months, implying that every month on average $28.7 \%$ of consumer prices were changed. Moreover, the frequencies of price changes were increasing over time. However, the analysis of the factors which determine the frequency of price changes in Latvia is missing. This paper is a follow-up of the project above, and our goal now is to discover the driving forces behind firms' decisions to adjust their prices.

To achieve this goal, we use various panel logit models, which explain the probability of observing a price change by a broad set of exogenous variables. The set of explanatory variables includes several macroeconomic variables describing observed economic conditions like inflation and demand faced by firms; it also includes characteristics of the preceding price changes, changes in tax rates, and seasonal and sector dummies. The methodology used in this paper is similar to one used by Aucremanne and Dhyne (2005) for Belgium, Lünnemann and Mathä (2005) for Luxembourg, Baumgartner et al. (2005) for Austria, and Baudry et al. (2007) for France.

The paper is structured as follows. Section 1 outlines the database used and provides short descriptive evidence on the price setting behaviour in Latvia. In Section 2, we briefly overview theoretical models of price setting, provide some details on panel logit models for the probability of a price change, and discuss the set of explanatory variables. Section 3 describes the results of the models. The last Section summarises the most important features of price formation mechanism in Latvia and provides some conclusions relevant to modelling and policy making. 


\section{DESCRIPTIVE EVIDENCE ON PRICE SETTING BEHAVIOUR IN LATVIA}

At first, we outline the database used as well as give a short descriptive analysis of price setting behaviour in Latvia. For the description of estimation methodology and more detailed results for product groups and sectors as well as individual products refer to Beņkovskis et al. (2010).

\subsection{Description of the database}

The database used in the current research is provided by the CSB and is generally used as a part of the database for Latvia's CPI calculations. The sample contains partially anonymous 6-digit COICOP records for prices of individual products (only 4-digit COICOP level is known) in a particular outlet at monthly frequency from January 2003 to December 2009 (84 months). The total number of records is 590016 for 185 products. There are 7024 individual product-outlet pairs with 13 to 71 outlet records per individual product per month (38 outlet records per product on average).

According to confidentiality restrictions, the statistical database used in this research does not contain data on products for which prices are available only from a very limited number of producers or outlets, e.g. heat, water, and telecommunication services. Therefore, it is necessary to stress that the sample does not cover all products (see Table 1).

Table 1

Sample coverage by COICOP groups (2009)

\begin{tabular}{lrrr}
\hline & Shares in CPI & $\begin{array}{r}\text { Shares in } \\
\text { sample }\end{array}$ & Coverage \\
\hline 1 Food and non-alcoholic beverages & 24.0 & 14.9 & 62.0 \\
2 Alcoholic beverages, tobacco & 7.1 & 6.0 & 84.5 \\
3 Clothing and footwear & 7.4 & 3.6 & 48.9 \\
4 Housing, water, electricity, gas and other fuels & 12.2 & 1.7 & 14.3 \\
5 Furnishing, household equipment and routine & & & \\
household maintenance & 5.5 & 2.8 & 51.3 \\
6 Health & 4.4 & 1.3 & 29.1 \\
7 Transport & 13.9 & 5.0 & 36.3 \\
8 Communication & 4.6 & 0.2 & 3.7 \\
9 Recreation and culture & 9.0 & 3.6 & 40.1 \\
10 Education & 1.3 & 0.1 & 4.6 \\
11 Restaurants and hotels & 5.5 & 2.6 & 46.9 \\
12 Miscellaneous goods and services & 5.0 & 2.4 & 47.4 \\
Total & $\mathbf{1 0 0 . 0}$ & $\mathbf{4 4 . 2}$ & $\mathbf{4 4 . 2}$ \\
\hline
\end{tabular}

Source: Beņkovskis et al. (2010).

Notes: Shares in CPI show the shares of particular groups in CPI basket in 2009 in \%. The share in the sample denotes the share of products from a particular group presented in our database in the CPI basket in 2009 in \%. Coverage indicates the share of products covered by our database within a group in 2009 in \%.

In addition to price levels, the price database provides information on two types of specific data issues which also need to be taken into account while performing the analysis of the price formation mechanism: first, the cases with the data point estimated rather than observed (imputations), and, second, the cases where a product is replaced by another similar product. Imputations are used by the CSB in the event 
of a short-term absence of product in an outlet (for a period of less than 2-3 months) or for seasonal products (the price is not posted year-round). The missed observations are obtained by extrapolating the data series based on the dynamics of other observable prices in the respective product group. Approximately $12 \%$ of price changes in the database can be attributed to price imputations. In this paper, we concentrate on the results which include price imputations. ${ }^{1}$ As regards product replacement, it almost always contains a shift in the price level, which, however, is not informative. Therefore, we account for this effect while calculating the price change series by throwing out the price change at the moment of replacement and, consequently, producing inner-left and inner-right censored spells within the time series.

\subsection{Main characteristics of consumer price setting mechanism}

The main indicators that describe the price formation mechanism are the frequency of price changes, duration of price spells (inversely related to frequency), and size of price changes. All these indicators are presented in Table 2. The frequency and duration have been calculated using frequency approach.

Table 2

Frequency and average size of price changes, duration of price spells by COICOP groups and product sectors (2003-2009)

\begin{tabular}{lrrr}
\hline & \multicolumn{2}{r}{ Frequency approach } & $\begin{array}{r}\text { Average price } \\
\text { change }\end{array}$ \\
\hline 1 Food and non-alcoholic beverages & Frequency & Duration & 0.019 \\
2 Alcoholic beverages, tobacco & 0.326 & 3.07 & 0.060 \\
3 Clothing and footwear & 0.198 & 5.06 & -0.065 \\
4 Housing, water, electricity, gas and other fuels & 0.260 & 3.85 & 0.058 \\
5 Furnishing, household equipment and routine household & 0.133 & 7.50 & \\
maintenance & & & 0.013 \\
6 Health & 0.168 & 5.97 & 0.172 \\
7 Transport & 0.066 & 15.09 & 0.019 \\
8 Communication & 0.701 & 1.43 & -0.052 \\
9 Recreation and culture & 0.441 & 2.27 & 0.074 \\
10 Education & 0.163 & 6.15 & 0.065 \\
11 Restaurants and hotels & 0.079 & 12.67 & 0.091 \\
12 Miscellaneous goods and services & 0.098 & 10.24 & 0.046 \\
Unprocessed food & 0.157 & 6.37 & 0.014 \\
Processed food & 0.377 & 2.65 & 0.025 \\
Energy & 0.246 & 4.06 & 0.023 \\
Services & 0.659 & 1.52 & 0.126 \\
Non-energy goods & 0.079 & 12.73 & 0.013 \\
Total & 0.208 & 4.81 & $\mathbf{0 . 0 3 1}$ \\
\hline
\end{tabular}

Source: Beņkovskis et al. (2010).

Notes: Frequency shows the average share of prices that are changed during one month. Duration denotes the average duration of price spells in months. Average price changes show the average logarithmic changes of prices. Table A1 in Appendix shows the classification of individual products by sector.

\footnotetext{
${ }^{1}$ Conclusions obtained from the models are not significantly altered by ignoring price imputations. Results
} are available upon request. 
Calculations in Benkovskis et al. (2010) show that each month during 2003-2009 $28.7 \%$ of consumer prices were changed on average. This means that the average duration of a price spell was approximately 3.5 months, implying quite a high degree of price flexibility. These figures are not homogenous for different types of products. The highest flexibility is observed for the prices of transport (average price spell duration of 1.4 months), communication (2.3 months), food and non-alcoholic beverages (3.1 months), and clothing and footwear (3.9 months) prices. On the other side, the lowest price flexibility was obtained for health (15.1 months), education (12.7 months), and restaurants and hotels (10.2 months). ${ }^{2}$ In the breakdown by sector, we find that price flexibility of the highest degree is observed for energy products (1.5 months) and unprocessed food ( 2.7 months), while the highest price rigidity is typical for services (12.7 months).

Along with the frequency and duration indicators that characterise price flexibility, the size of price changes is also an important feature of the price formation mechanism. The average consumer price change in 2003-2009 was 3.1\%, although this indicator is rather heterogeneous as well. For instance, the largest changes are observed for health (17.2\%), restaurant and hotel (9.1\%), and recreation and culture (7.4\%) prices. At the same time, the average change of clothing and footwear as well as communication prices was even negative $(-6.5 \%$ and $-5.2 \%$ respectively).

Several useful conclusions about the price formation mechanism can be drawn from analysing the upward and downward price changes separately. Table 3 shows frequency and average size of price increases and decreases by group and product sector.

According to Benkovskis et al. (2010), during the investigated time period price increases occurred almost 1.6 times more often than price decreases: on average, $17.8 \%$ of prices were changed upwards each month, while only $11.0 \%$ of prices were revised downwards. This asymmetry when positive price changes are more probable than negative ones was typical for almost all groups and sectors. The only exceptions are communication prices as well as recreation and culture prices. The highest asymmetry between upward and downward price revisions is observed in restaurants and hotels $(8.1 \%$ and $1.6 \%$ respectively), health $(6.1 \%$ and $0.6 \%)$, and alcoholic beverages and tobacco $(14.8 \%$ and $4.9 \%)$. The latter is, to a large extent, driven by changes in excise tax rates. As to product sectors, there is a tendency that the largest asymmetry was recorded for the least flexible services sector $(6.7 \%$ and $1.1 \%$ respectively), while the smallest in the most flexible sectors of unprocessed food $(22.2 \%$ and $15.5 \%)$ and energy ( $40.3 \%$ and $25.6 \%)$.

The asymmetry in the average size of price increases and decreases was not so pronounced: the average consumer price increase during 2003-2009 was $10.3 \%$, while the average decrease was only slightly higher, at $11.9 \%$. For most groups and sectors, the size of upward and downward price revisions was rather similar. A clear

\footnotetext{
2 We should take into account coverage problems for some product groups (transport, communications, education and health). The high flexibility of transport prices was led by the high flexibility of fuel prices, while the purchase of vehicles and transport services with obviously lower price flexibility were underrepresented in our database. A similar problem is in communication, as we have no data on postal and telephone services. Therefore, it could be argued that the flexibility of prices in transport and communication sectors is overestimated. As for health and education, the prices of missing products are also expected to be rather rigid.
} 
outlier in this respect was the clothing and footwear sector, for which the size of positive price changes $(7.3 \%)$ was significantly smaller than the size of negative ones $(21.2 \%)$. We can also observe a strong negative correlation between the price flexibility and average absolute size of price changes (see Table 3 ).

Table 3

Frequency and size of upward and downward prices changes by COICOP group and product sector (2003-2009)

\begin{tabular}{lrrrrrr}
\hline & \multicolumn{3}{c}{ Frequency } & & \multicolumn{2}{c}{ Size } \\
\cline { 2 - 7 } & All & Upward & Downward & All & Upward & Downward \\
\hline 1 Food and non-alcoholic beverages & 0.326 & 0.198 & 0.128 & 0.019 & 0.107 & 0.125 \\
2 Alcoholic beverages, tobacco & 0.198 & 0.148 & 0.049 & 0.060 & 0.100 & 0.071 \\
3 Clothing and footwear & 0.260 & 0.159 & 0.101 & -0.065 & 0.073 & 0.212 \\
4 Housing, water, electricity, gas and other & & & & & \\
fuels & 0.133 & 0.098 & 0.036 & 0.058 & 0.115 & 0.111 \\
5 Furnishing, household equipment and & & & & & \\
routine household maintenance & 0.168 & 0.105 & 0.062 & 0.013 & 0.079 & 0.111 \\
6 Health & 0.066 & 0.061 & 0.006 & 0.172 & 0.197 & 0.159 \\
7 Transport & 0.701 & 0.426 & 0.274 & 0.019 & 0.051 & 0.054 \\
8 Communication & 0.441 & 0.045 & 0.397 & -0.052 & 0.052 & 0.064 \\
9 Recreation and culture & 0.163 & 0.076 & 0.087 & 0.074 & 0.137 & 0.141 \\
10 Education & 0.079 & 0.055 & 0.023 & 0.065 & 0.143 & 0.121 \\
11 Restaurants and hotels & 0.098 & 0.081 & 0.016 & 0.091 & 0.128 & 0.105 \\
12 Miscellaneous goods and services & 0.157 & 0.100 & 0.057 & 0.046 & 0.136 & 0.150 \\
\hline Unprocessed food & 0.377 & 0.222 & 0.155 & 0.014 & 0.109 & 0.125 \\
Processed food & 0.246 & 0.160 & 0.086 & 0.025 & 0.104 & 0.123 \\
Energy & 0.659 & 0.403 & 0.256 & 0.023 & 0.061 & 0.058 \\
Services & 0.079 & 0.067 & 0.011 & 0.126 & 0.161 & 0.133 \\
Non-energy goods & 0.208 & 0.127 & 0.081 & 0.013 & 0.092 & 0.127 \\
Total & $\mathbf{0 . 2 8 7}$ & $\mathbf{0 . 1 7 8}$ & $\mathbf{0 . 1 1 0}$ & $\mathbf{0 . 0 3 1}$ & $\mathbf{0 . 1 0 3}$ & $\mathbf{0 . 1 1 9}$ \\
\hline
\end{tabular}

Source: Benkovskis et al. (2010).

Notes: Frequency shows the average share of prices that are changed during one month. Average price change shows the average logarithmic change of prices. Table A1 in Appendix shows the classification of individual products by sectors.

Another interesting question related to the price formation mechanism and frequency of price decreases is the role of sales. We define sales as a temporary price decrease (for one month) with a subsequent price increase to the previous level. The share of such temporary price decreases is analysed in Table 4.

Benkkovskis et al. (2010) report that in $13.5 \%$ of cases the consumer price decreases were just temporary decreases or sales, without any long-term effect on the overall price level. Sales were mostly used in the sectors of processed food $(23.5 \%$ of all price decreases) and non-energy goods $(15.3 \%)$, while the practice was not typical for price formation in the services (5.1\%) and energy (5.5\%) sectors. The analysis of sales by product group shows that sales were very often used for miscellaneous goods and services (35\%, with an obvious predominance of goods), furnishing, household equipment and routine household maintenance $(17.6 \%)$ as well as alcoholic beverages and tobacco $(15.5 \%)$. The mechanism of sales was rarely used in the sectors of communication (3.5\%), education (4.0\%), restaurants and hotels (4.5\%), and transport (5.1\%). 
Table 4

Number of price decreases and sales by COICOP groups and product sectors (2003-2009)

\begin{tabular}{|c|c|c|c|}
\hline & Price decreases & Sales & Share of sales \\
\hline 1 Food and non-alcoholic beverages & 29373 & 4027 & 13.7 \\
\hline 2 Alcoholic beverages, tobacco & 1777 & 276 & 15.5 \\
\hline 3 Clothing and footwear & 4324 & 318 & 7.4 \\
\hline 4 Housing, water, electricity, gas and other fuels & 742 & 112 & 15.1 \\
\hline \multicolumn{4}{|l|}{5 Furnishing, household equipment and routine } \\
\hline household maintenance & 2306 & 407 & 17.6 \\
\hline 6 Health & 405 & 38 & 9.4 \\
\hline 7 Transport & 3888 & 200 & 5.1 \\
\hline 8 Communication & 1809 & 63 & 3.5 \\
\hline 9 Recreation and culture & 2197 & 294 & 13.4 \\
\hline 10 Education & 25 & 1 & 4.0 \\
\hline 11 Restaurants and hotels & 449 & 20 & 4.5 \\
\hline 12 Miscellaneous goods and services & 2766 & 984 & 35.6 \\
\hline Unprocessed food & 20693 & 1989 & 9.6 \\
\hline Processed food & 8680 & 2038 & 23.5 \\
\hline Energy & 3725 & 204 & 5.5 \\
\hline Services & 800 & 41 & 5.1 \\
\hline Non-energy goods & 16163 & 2468 & 15.3 \\
\hline Total & 50061 & 6740 & 13.5 \\
\hline
\end{tabular}

Source: Beņkovskis et al. (2010).

Notes: Sales are defined as a temporary price decrease (for one month) with a subsequent price increase to the previous level. The share of sales is in \%. Table A1 in Appendix shows the classification of individual products by sectors.

An advantage of the frequency approach is that it allows analysing not only a whole sample period but also each particular month; as a result, we are able to draw a continuous time-line for frequencies of price changes during 2003-2009. Figure 1 shows that frequencies of all price changes exhibit a clear upward change during the analysed time period. In 2003, the frequency of price changes fluctuated around $22 \%$, while in 2009 it exceeded $30 \%$. The increase over time was rather steady, although there was one noticeable spike at the beginning of 2009 when more than $60 \%$ of all prices were changed during one month. It can most probably be explained by a VAT rate increase from $18 \%$ to $21 \%$ in January 2009 . The frequency of price changes was also high in February most likely due to the changes in excise tax rates and the lagged effects of the VAT increase.

It is possible to make the same analysis of positive and negative price changes separately. Although the pattern is not as clear in this case, some interesting facts can be noted. First, until the end of 2008, the frequency of upward price changes exceeded that of downward price changes, this being especially pronounced in 2007. Then, as of the last months of 2008, the frequency of negative price changes was similar to or slightly above the frequency of positive price changes, with January and February 2009 as an exception due to tax rate changes. Second, until the end of 2008 , an increase in the frequency of price changes was driven by positive price changes, while the frequency of negative price changes was fluctuating around $10 \%$. In the period of economic recession, however, the frequency of negative price revisions increased to almost $20 \%$. 
Figure 1

Frequency of price changes over time for all prices (2003-2009)
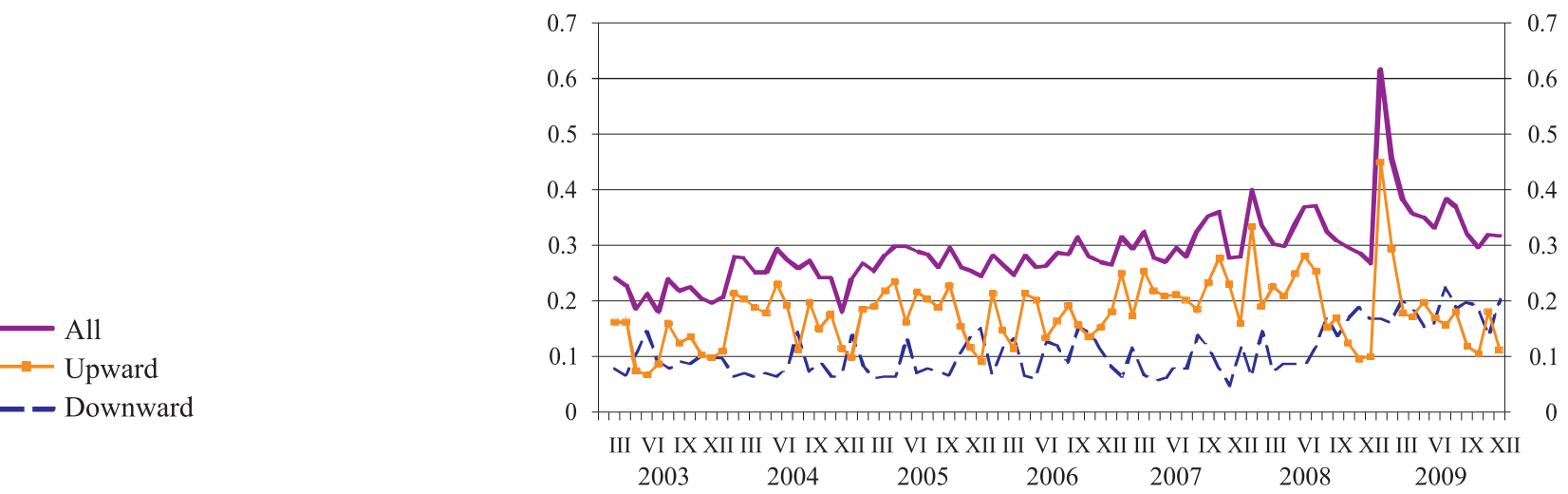

Source: Benkovskis et al. (2010).

Note: Frequency shows the average share of prices that are changed during one month.

In a similar way, a detailed investigation of the tendencies in the average size of upward and downward price changes can be made. Figure 2 indicates that the average size of price changes was increasing over time as well. For positive price changes, it went up from $6 \%-7 \%$ in 2003 to almost $10 \%$ at the end of 2007 . Then a temporary decrease was observed, although in 2009 it rebounded to $10 \%$ level. As to the downward price changes, the average size of a decrease was fluctuating between $6 \%$ and $8 \%$ in 2003-2007, and a significant increase in size is observed during the crisis period - at the end of 2009 a typical price revision downward was $12 \%$.

Figure 2

Size of price changes over time for all prices (2003-2009)

$\because$ Upward

- - Downward

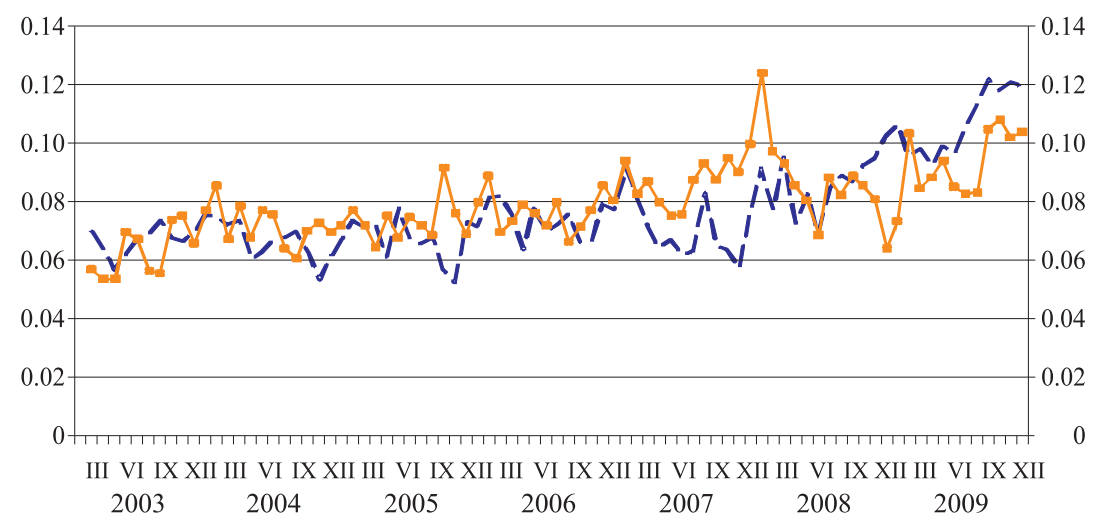

Source: Beņkovskis et al. (2010).

Note: The size of price changes shows the average logarithmic change of prices. 


\section{THEORETICAL AND EMPIRICAL MODELS OF PRICE SETTING MECHANISM}

Now follows a brief overview of theoretical models of price setting by discussing the main difference between the time-dependent and state-dependent pricing. Furthermore, we provide an insight into the probability of a price change by explaining logit models and discussing a set of exogenous variables.

\subsection{Time-dependent and state-dependent pricing models}

Based on the assumptions about factors underlying the price change frequency, the theoretical models can broadly be classified as time-dependent pricing models where price changes are determined exogenously at fixed or randomly selected times (Taylor, 1980, Calvo, 1983), and state-dependent pricing models where the frequency of price changes depends on the state of the economy (e.g. Cecchetti, 1986, Caplin and Spulber, 1987). Some models combine both elements (e.g. Dotsey et al., 1999).

In the staggered contract model developed by Taylor (1980), prices are set for a fixed number of periods and in each period a fixed fraction of firms change their contract prices. Calvo (1983) modified the Taylor model by suggesting that contracts end randomly according to a geometric distribution, thus developing a random duration version of the model where some fixed percentage of firms change their prices in every period. Both models feature exogenous staggering of price change in the economy over fixed or randomly selected periods, with a constant fraction of firms adjusting their prices in every period. The time-dependent pricing approach implies that the probability of a price change does not depend on the state of the economy; therefore, despite being widely used, this approach is criticised as not completely describing the sticky price mechanism.

The main assumption behind the state-dependent pricing is that prices are sticky because firms face costs of adjusting their prices (Rotemberg, 1982a, 1982b). Therefore, a firm will adjust the price when benefits from the price change will exceed expenses of the price change. Cecchetti (1986) showed that under the assumption of fixed price adjustment the probability of changing the price depends on various variables describing the last price change, inflation and demand; thus, the frequency of price changes depends on the state of the economy. The menu cost can be specified as fixed, as in Caplin and Spulber (1987), or random, as in Dotsey et al. (1999). The latter model presents a combination of Calvo approach with statedependent price setting features.

\subsection{Logit model of probability of price change}

The methodology described in this subsection is based on Aucremanne and Dhyne (2005) who used a panel data approach to find the factors determining the probability of a price change in Belgium. Similar approach was also used by Lünnemann and Mathä (2005) for Luxembourg, Baumgartner et al. (2005) for Austria, and Baudry et al. (2007) for France.

To model the probability of a price change we need to focus on the events of a price change while ignoring the size of price change, therefore we define $Y_{j k t}$ as a binary variable: 
$Y_{j k t}=\left\{\begin{array}{llc}1 & \text { if } & P_{j k t} \neq P_{j k . t-1} \\ 0 & & \text { otherwise }\end{array}\right.$

where $Y_{j k t}$ indicates whether price of product $j$ sold by firm $k$ is changed at the beginning of period $t,{ }^{3}$ and $P_{j k t}$ is price quote of individual product $j$ sold by firm $k$ at period $t$.

The choice of explanatory variables for the model crucially depends on the assumption about the underlying price formation mechanism. If we assume that price setters apply a Calvo (1983) pricing rule, then the probability of adjusting the price does not depend on the time elapsed since the previous price change or on the state of the economy, and the only explanatory variable will be a constant. In this case, the logit model of probability that firm $k$ changes the price of product $j$ at the beginning of period $t$ is the following:

$\operatorname{Pr}\left(Y_{j k t}=1\right)=\frac{\exp \left(\beta_{0}\right)}{1+\exp \left(\beta_{0}\right)}$

Under the assumptions of a Calvo pricing rule, the probability of price change is described only by $\beta_{0}$. The larger $\beta_{0}$ is, the less rigid are the prices. Equation (2) can be easily transformed to include also the elements of Taylor (1980) model, which assumes that firms adjust their prices after a fixed number of periods since the last price change. This is done by stating that truncation occurs after a fixed number of periods (there is a maximal length of a price spell specific to each product and firm).

If we assume a state-dependent pricing rule, then, following Cecchetti (1986), firm $k$ will change the price of product $j$ only if the difference between desired price $P_{j k t}^{*}$ and actual price $P_{j k t}$ exceeds a constant threshold $h_{j k}^{*}$ (specific for each product and firm):

$\operatorname{Pr}\left(Y_{j k t}=1\right)=\operatorname{Pr}\left(\ln \left(\frac{P_{j k t}^{*}}{P_{j k t}}\right) \geq h_{j k}^{*}\right)$

According to Cecchetti (1986), the probability that the difference between desired and actual price exceeds a certain threshold can be expressed in terms of several explanatory variables: accumulated inflation since the previous change of the price, time elapsed since the last price change, size of the last price change and accumulated change in demand variable since the previous price adjustment. This leads us to the following logit representation of the state-dependent pricing:

\footnotetext{
3 Our definition of a price change differs from the one used in Aucremanne and Dhyne (2005) who assumed that price changes occur at the end of period $t$. The data do not allow us to distinguish whether price changes typically occur at the end or the beginning of the month. However, it could be argued that tax changes usually come in force on the first day of the month, therefore our definition seems to be more reasonable at least in this case. It should be stressed that the usage of alternative definition will not lead to incomparability of results, except for seasonal effects.
} 


$$
\operatorname{Pr}\left(Y_{j k t}=1\right)=\frac{\exp \left(\beta_{0}+\sum_{i=1}^{N} \beta_{i} X_{i, j k t}\right)}{1+\exp \left(\beta_{0}+\sum_{i=1}^{N} \beta_{i} X_{i, j k t}\right)}
$$

where $X_{i, j k t}$ denotes an exogenous variable from the list above.

Equation (4) can be viewed as an extension of equation (2); moreover, it allows to test whether all price setters in the economy are time-dependent. Obviously, if $\beta_{1}, \ldots, \beta_{N}$ are not significantly different from 0 , we can conclude that all firms follow a Calvo pricing rule. On the other hand, significant estimates for any of $\beta_{1}, \ldots, \beta_{N}$ could be interpreted as a rejection of the Calvo model. Aucremanne and Dhyne (2005) argue that the estimates of $\beta_{1}, \ldots, \beta_{N}$ capture both the impact of the associated variable on the probability of price change and the share of this particular behaviour; it is not possible to identify both effects separately. Therefore, the rejection of Calvo model will not mean that there are no price setters which follow this rule in the economy. Rather, it would indicate that there is a significant share of firms following the state-dependent pricing model.

\subsection{Factors describing probability of price change}

Here we describe the variables used in the logit model to investigate factors affecting the frequency of consumer price changes in Latvia.

Inflation

Under the state-dependent pricing assumption according to Cecchetti (1986), the accumulated overall inflation since the last price adjustment should be among the explanatory variables. Larger accumulated inflation is associated with shorter duration between price changes. In empirical researches, the approaches to measure accumulated inflation differ. Aucremanne and Dhyne (2005) altered Cecchetti (1986) specification through substituting accumulated aggregate inflation by accumulated inflation measured at the sectoral level, while the changes in overall inflation were taken into account by a set of year dummies. The same approach was used in Baumgartner et al. (2005), while Lünnemann and Mathä (2005) used accumulated price changes at a very disaggregated 10-digit COICOP level.

We proceed by including various measures of accumulated consumer price inflation at different levels of aggregation as explanatory variables in the model. First, we use accumulated inflation since the last price adjustment at the 6-digit COICOP level $\left(\pi_{j k, t-T, t}^{\text {product }}\right)$, thus including inflation at the most detailed level which is available to us. ${ }^{4}$ Second, we include accumulated inflation at the corresponding 2-digit COICOP level $\left(\pi_{j k, t-T, t}^{\text {group }}\right)$, which describes price changes at the group level. Finally, following the theoretical model of Cecchetti (1986), accumulated overall inflation since the last price change $\left(\pi_{j k, t-T, t}^{\text {total }}\right)$ is used. Logarithmic changes of prices were used in all

${ }^{4}$ Inflation at the 6-digit COICOP level was constructed using the database provided by CSB and assuming equal weights for all outlets. 
cases. The inclusion of all three measures will allow us to make additional conclusions about the price formation mechanism, e.g. whether firms' decisions are affected by the total inflation level in the economy or they are more focused on price changes in a particular market. Mackowiak and Wiederholt (2009), using the model of sticky prices under rational inattention, suggest that firms pay more attention to idiosyncratic conditions than to aggregate conditions, as idiosyncratic conditions could be more variable or more important. According to this theoretical model, firms' decisions are expected to depend on price changes in a particular product market.

Time since the last price adjustment

The time passed since the last price adjustment is an important explanatory variable both in state-dependent and time-dependent pricing models. On the one hand, using the target-threshold model Cecchetti (1986) proved, both theoretically and empirically, that the longer the period since the last price change, the greater the probability of observing another price change. On the other hand, the Taylor model assumes the truncation of a price spell after a fixed period of time.

To account for these effects, we use two types of time variables in the logit model. First, we include the logarithm of the period of time elapsed since the last price change $\left(T_{j k t}\right)$. According to the theory, the coefficient before this variable is expected to be positive. Second, following Aucremanne and Dhyne (2005), we test for possible price spell truncations as in the Taylor model notations by including a set of dummy variables $\left(d u r 1_{j k t}, d u r 2_{j k t}, d u r 3_{j k t}, d u r 4_{j k t}, d u r 6_{j k t}, d u r 9_{j k t}\right.$ and $d u r 12_{j k t}$ ) which are equal to 1 , if the period of time since the last price adjustment is $1,2,3,4,6,9$ or 12 months respectively. A positive and statistically significant coefficient before a dummy variable will indicate that a significant share of firms follow the time-dependent rule by changing prices after a certain number of months (although it will not allow us to distinguish between a regular Taylor contract and irregular truncated Calvo rule).

\section{Size of the last price change}

Cecchetti (1986) argues that the size of the previous price adjustment may contain information about the next price change. If the previous price change was large, it could indicate that the threshold for changing prices is high and firms are forced to change prices less frequently, although by larger amounts. Likewise, a small previous price adjustment could indicate that the threshold is low and prices can change more frequently. Therefore, we introduce a variable which shows the size of the previous price logarithmic change ( $\left.l d p_{j k t}\right)$. Moreover, to account for possible asymmetries, we distinguish between the cases where previous price adjustments are positive and the cases where those are negative. It is done by using a dummy variable ( $\left.l d p d w_{j k t}\right)$, which is equal to 1 if the previous price changes were negative.

\section{Demand variable}

The theoretical and empirical model of Cecchetti (1986) shows the importance of the demand factor (presented by the amount of industry sales) for the frequency of price changes. According to his empirical model for magazine prices, the effect of demand on the probability of price adjustment is positive and statistically significant. Unfortunately, there is no sales data at the firm or product level for 
Latvia. We also do not have a full data set on the sector level, as information on services trade volumes is rather scarce. Therefore, we are restricted to the overall demand variable, which is defined as the accumulated logarithmic change in the total retail trade turnover at constant prices since the last price change ( trade $\left._{j k, t-T, t}\right)$.

Tax rate changes

Following Aucremanne and Dhyne (2005), we test for the price reaction of firms to VAT rate shocks. Instead of using a simple binary variable, we describe the VAT tax change as follows:

$$
v a t_{j t}=\ln \left(\frac{1+t_{t}^{V A T}}{1+t_{t-1}^{V A T}}\right)
$$

where $v a t_{j t}$ is VAT rate change at the beginning of period $t, t_{t}^{V A T}$ is VAT rate for product $j$ at period $t$. This definition of the variable allows us to account for the size of tax rate change. As in Aucremanne and Dhyne (2005), we distinguish between the tax rate increases and decreases by splitting $v a t_{j t}$ into two variables: $v a t_{j t}^{+}$for increases and $v a t_{j t}^{-}$for decreases. Insufficient level of disaggregation (we have only partly anonymous 6-digit COICOP records, so only 4-digit level is known) does not allow constructing a similar variable for excise tax rate changes.

Attractive prices

The frequency of price changes could be affected by psychological effects and marketing strategies. One effect, which is usually included in the logit models of price changes, is the effect of an attractive price. Like in Aucremanne and Dhyne (2005), we define the attractive price as a price ending with digits 9,5 or 0 . The attractive price effect in the model is indicated by dummy variable $\left(a t p_{j k t}\right)$. It is expected that firms prefer attractive prices to other prices and adjust the former less frequently.

Seasonal and year effects

The frequency of price changes may display seasonal patterns, which, to some extent, will be captured by variable $\left(d u r 12_{j k t}\right)$. However, it will not allow determining in which particular month price adjustments typically occur. Therefore, we introduce a set of monthly dummies $\left(\right.$ month $_{1, t}, \ldots$, month ${ }_{11, t}$, with December as a baseline month) to account for this effect. In addition, the year dummies $\left(\right.$ year $_{2004, t}, \ldots$, year $_{2009, t}, 2003$ as a baseline year) are included to capture changes in the price setting mechanism that are not explained by other factors in the model. Therefore, these variables can be interpreted as the effect of omitted macroeconomic conditions, e.g. the demand and supply factors.

Sector variables

Finally, the price formation mechanism obviously could differ across firms and outlets by product sector. This effect is captured by a set of explanatory variables $\left(\sec t o r_{i, j}\right)$, which includes dummy variables for the main product sectors of 
unprocessed food, energy, services and non-energy goods $\left(\operatorname{profood}_{j}\right.$, energy $_{j}$, services $_{j}$, nonenergy $_{j}$, unprocessed food as a baseline).

The logit representation of state-dependent pricing described in equation (4) is now extended allowing random effects $u_{j k}$ which are specific for all product-firm pairs:

$\operatorname{Pr}\left(Y_{j k t}=1\right)=\frac{\exp \left(X_{j k t} \beta+u_{j k}+\varepsilon_{j k t}\right)}{1+\exp \left(X_{j k t} \beta+u_{j k}+\varepsilon_{j k t}\right)}$

where $X_{j k t}$ is row vector of exogenous variables, $\beta$ is column vector of logit model's coefficients, and $\varepsilon_{j k t}$ is error term. $X_{j k t} \beta$ can be written as follows:

$X_{j k t} \beta=\beta_{0}+\beta_{1} \pi_{j k, t-T, t}^{\text {product }}+\beta_{2} \pi_{j k, t-T, t}^{\text {group }}+\beta_{3} \pi_{j k, t-T, t}^{\text {total }}+\beta_{4} v a t_{j t}^{+}+\beta_{5} v a t_{j t}^{-}+\beta_{6}$ trade $_{j k, t-T, t}$

$+\beta_{7} \ln \left(T_{j k t}\right)+\beta_{8} d u r 1_{j k t}+\beta_{9} d u r 2_{j k t}+\beta_{10} d u r 3_{j k t}+\beta_{11} d u r 4_{j k t}+\beta_{12} d u r 6_{j k t}$

$+\beta_{13} d u r 9_{j k t}+\beta_{14} d u r 12_{j k t}+\beta_{15} l d p_{j k t} l d p d w_{j k t}+\beta_{16} l d p_{j k t}\left(1-l d p d w_{j k t}\right)$

$+\beta_{17} a_{\text {atp }}+\sum_{i=1}^{11} \alpha_{i}$ month $_{i, t}+\sum_{i=2004}^{2009} \delta_{i}$ year $_{i, t}+\sum_{i=2}^{N} \theta_{i} \sec$ tor $_{i, j}$

We also use different definitions for dependent variable $Y_{j k t}$, distinguishing between all price changes and price changes excluding sales. Sales are defined as a temporary price decrease for one month with a consecutive price increase to the previous level. 


\section{RESULTS OF THE MODEL}

In this Section the results obtained from the logit model described in equations (6) and (7) are discussed. First, we provide results explaining the probability of observing a consumer price change in Latvia. Then we show the results for upward and downward price revisions separately. Finally, we explain the probability of observing a temporary price reduction (sales).

\subsection{Explaining probability of price change}

The results of all price changes (both, including and excluding sales) are presented in Table A2 in Appendix. We will discuss the results of logit model for the probability of observing an adjustment in Latvia's consumer prices and compare them with the studies on other countries by the main blocks of explanatory variables.

Accumulated inflation

Coefficients before accumulated inflation variables in Table A2 show that Latvia's firms (or at least a significant share of them) follow the state-dependent pricing strategy, as some coefficients are positive and statistically significant. Therefore, we can conclude that these results confirm the theoretical predictions of Cecchetti (1986), and higher inflation leads to more frequent price adjustment in Latvia.

Moreover, our results show that the price decisions of Latvian firms are mostly driven by overall inflation and only to some extent by inflation at the group level. The coefficients before accumulated inflation at product level did not turn out to be statistically significant. This conclusion is valid for the price changes both including and excluding sales. The increase in overall accumulated inflation by 1 percentage point enlarges the probability of a price adjustment by 0.88 percentage point (including sales) or by 0.77 percentage point (excluding sales). The increase in accumulated inflation at the product group level by 1 percentage point has a much smaller effect and increases the probability of a price change only by 0.03 percentage point. It follows that firms mostly react to the macroeconomic situation in the country and are rather insensitive to price dynamics in a particular product market.

A positive link between accumulated inflation and probability of a price change was observed also in other EU countries. Aucremanne and Dhyne (2005) state that the probability to observe a price change in Belgium is in a significant way an increasing function of the accumulated sectoral inflation since the last price change. Lünnemann and Mathä (2005) report that a 1 percentage point increase in accumulated price inflation increases the probability of observing a price change by 0.5 percentage point in Luxembourg. Much higher figures are reported for Austria in Baumgartner et al. (2005). According to them, an increase in the accumulated monthly inflation rate by 1 percentage point pushes the probability for a price change up by 18 percentage points. Baumgartner et al. (2005) explain such a large impact by a low inflation rate during the sample period.

Accumulated changes in demand

The probability of observing consumer price adjustment positively and statistically significantly depends on the accumulated changes in overall demand, which in our model is proxied by changes in total retail trade turnover at constant prices. An 
increase of 1 percentage point in the accumulated changes of trade turnover pushes the probability of a price change up by 0.06 (including sales) or 0.05 (excluding sales) percentage point, indicating that compared with the accumulated inflation the demand factor is less important for the price setting behaviour. It is also possible that firms are more sensitive to demand conditions at more disaggregated level.

Time elapsed since the last price change

The coefficient before the price spell duration is negative and statistically significant, which contradicts to theoretical considerations, as we were expecting the probability of price change to increase with more time elapsing since the last price change. Aucremanne and Dhyne (2005) explain this result by unobserved heterogeneity, which cannot be removed completely from the model. As a result, the negative effect of duration emerges when aggregating different products.

The coefficients before dummy variables capturing the time elapsed since the last price adjustment show that the time-dependent price setting behaviour is also quite popular among the Latvian firms. The probability of price change is statistically significantly higher for the price spells with duration of 1,9 and 12 month. The largest marginal effect is observed for 12-month truncation (8.2 percentage points), which is obviously related to seasonality and shows that a certain part of firms change prices if the price spell has survived 12 months (as argued before, here we cannot distinguish between the firms changing prices every year at a particular month and the firms doing it irregularly). The positive coefficient for truncation at 1 month (prices are changed next month after the previous adjustment) remains statistically significant only when sales are included; hence we can conclude that one month truncation is not observed for permanent price adjustments.

Similar results were found for Austria by Baumgartner et al. (2005), reinforcing the evidence of Taylor-type phenomena for durations of 12 months and to a lesser extent for durations of 1 month, 2 and 3 years. Lünnemann and Mathä (2005) state that the dummies representing truncations at $1,5,6,12$ and 24 months contribute positively to the probability of price change in Luxembourg.

Size of the last price change

With regard to the size of the last price change, the larger the size of the negative preceding price adjustment, the greater the probability of observing a price change (note, that a larger negative increase implies a larger negative size of factor $\left.l d p_{j k t} l d p d w_{j k t}\right)$. An increase of 1 percentage point in the size of the preceding price reduction raises the probability of price change by 0.29 percentage point. However, this effect contracts to only 0.03 percentage point, if we analyse permanent price changes; hence the previously mentioned effect is largely driven by sales. On the other hand, sizeable price increases diminish the probability of price change: an increase of 1 percentage point in the size of the preceding price rise reduces the probability of observing a price change by 0.19 percentage point $(0.13$ percentage point for permanent price adjustments).

Lünnemann and Mathä (2005) report that a sizeable price reduction in the past increases the probability of a price change (by 0.04 percentage point), while the size of a preceding price increase does not affect the probability of price change significantly. Also Baumgartner et al. (2005) and Aucremanne and Dhyne (2005) state that the effect of the size of the last price decrease on the probability of price 
change is much stronger than the effect of the size of a price increase. However, it is possible that these results are driven by the presence of sales in the analysis and, therefore, are not contradicting our findings.

Seasonality

Seasonal patterns of the probability of observing a price change are presented in Figure 3 which shows an additional probability of a price change compared with December.

Figure 3

Seasonality in probability of observing price change

Including sales

Excluding sales

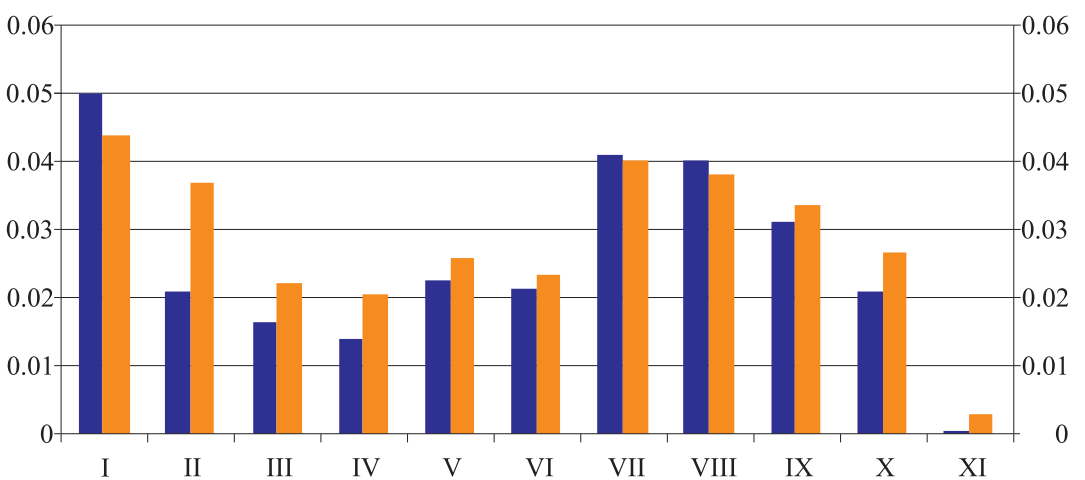

Source: Authors' calculations.

Notes: Seasonal effects show an additional probability of observing a price change compared with December. Figure presents the results from Table A2 in Appendix.

The probability of price adjustment at the beginning of December is the lowest, as all coefficients before the seasonal dummies are positive (and all statistically significant, except for November). The largest probability of price change is observed at the beginning of January (by 4.4-5.0 percentage points larger than in December), July and August (by 3.8-4.1 percentage points larger). The result for January could be interpreted as a Christmas effect (as mentioned before, we cannot distinguish between price changes at the beginning of January and the end of December), while the high frequency of price changes in July and August could be related to the changes in prices of food and clothes. The seasonal pattern is rather similar regardless of whether we use all price changes or price changes excluding sales. This seasonal pattern of price changes is very similar to the one found by Baudry et al. (2007) for France.

Attractive prices

Psychological effects have a significant impact on price setting as attractive prices statistically significantly increase price rigidity. The probability to observe a change of attractive prices is by 4.4-4.5 percentage points lower compared with unattractive prices. These results are qualitatively and quantitatively in line with the conclusions made in other empirical researches referred to above.

VAT rate change

Not surprisingly, a VAT rate change has significant influence on the price setting behaviour of firms in Latvia. Both upward and downward changes in the VAT rate increase the probability of observing price adjustment, although with a sign of asymmetry: a VAT rate increase by 1 percentage point increases the probability of a price change by $8.8-8.9$ percentage points, while a VAT rate decrease by 
1 percentage point increases the probability of a price change only by $1.3-$ 1.4 percentage points.

Year dummy variables

The estimated coefficients before year dummies include all time effects which are not captured by other variables in our model. The results show that there is an increasing trend in price flexibility, which cannot be explained by other variables: inflation, demand, tax changes, etc. According to our calculations, the probability of observing price adjustments in 2009 was by $10.7-12.7$ percentage points higher than in 2003, keeping other explanatory variables fixed. The reasons behind such differences will be discussed in the next subsection where the cases of upward and downward price revisions will be analysed separately.

Sectoral dummy variables

After controlling for other factors, the most flexible prices are in the energy sector (mostly fuel, with the probability of a price change by 25.4-26.6 percentage points higher than for unprocessed food prices), while services prices are the most rigid (the probability of a price change is by 19.7-22.4 percentage points lower than for unprocessed food prices). These conclusions are in line with those obtained by Beņkovskis et al. (2010) and described in Section 1.

Overall, we can conclude that the consumer price formation in Latvia is a combination of both state-dependent and time-dependent behaviour. On the one hand, the frequency of price changes depends on inflation (mostly aggregate inflation, but to a lesser extent on group-level inflation), demand conditions, size of last prices changes, and changes in tax rates. On the other hand, we see some elements of time-dependent price setting, e.g. price truncation in 12 months after the last price change, and a strong seasonal pattern. We also find an increase in the price flexibility which cannot be explained by factors included in the model, and strong heterogeneity in the probability of adjusting prices across different product sectors.

\subsection{Distinguishing between price increases and decreases}

In the previous subsection, we modelled the probability of all price changes, either positive or negative. The next step of our analysis is to distinguish between these two cases, as it is likely that the factors behind price setting differ in cases of upward and downward price revisions.

The set of explanatory variables in the logit equation remains unchanged, but we use different binary variables indicating positive $\left(Y_{j k t}^{+}\right)$and negative $\left(Y_{j k t}^{-}\right)$price changes:

$Y_{j k t}^{+}=\left\{\begin{array}{ccc}1 & \text { if } & P_{j k t}>P_{j k . t-1} \\ 0 & & \text { otherwise }\end{array}, Y_{j k t}^{-}=\left\{\begin{array}{ccc}1 & \text { if } & P_{j k t}<P_{j k . t-1} \\ 0 & & \text { otherwise }\end{array}\right.\right.$

Table A3 in Appendix shows the results of logit model for price increases (including and excluding sales) and Table A4 presents the results of price decreases (including and excluding sales). As before, we discuss the most important results by blocks of explanatory variables. 


\section{Accumulated inflation}

The coefficients before accumulated inflation variables in Tables A3 and A4 show that higher inflation increases the probability of observing a positive price change, while lower inflation (or higher deflation) increases the probability of observing a price reduction. These conclusions are unchanged when sales are included or excluded. The most interesting observation, however, derives from the fact that the decisions on price increases or decreases depend on different aggregation levels of inflation. As before, the probability of price increase mostly depends on accumulated overall inflation, the impact of accumulated inflation on a group level is marginal, and the effect of price changes of a particular product is not statistically significant. An increase of 1 percentage point in total accumulated inflation leads to a 0.82 percentage point higher probability of a price rise $(0.68$ percentage point if sales are excluded). The effect of 1 percentage point increase in accumulated inflation at the group level on the probability of a price increase is much lower 0.04 percentage point.

The probability of price decrease also depends on overall accumulated inflation. However, in contrast to upward price revisions, the probability of price decrease depends on accumulated price changes at the product level as well. Moreover, in both models (including and excluding sales) the coefficients before product price changes are only twice smaller than those before overall accumulated inflation. The increase in accumulated total inflation diminishes the probability of price reduction by $0.10-0.11$ percentage point, while the increase in accumulated inflation for individual products diminishes the probability by 0.06 percentage point. We can conclude that firms decide to increase the prices observing the overall macroeconomic situation with prices, while when deciding to reduce prices, they take into account both the price changes of particular product and macroeconomic conditions. This result contradicts the model of Mackowiak and Wiederholt (2009) which stresses the importance of idiosyncratic conditions. Although it is difficult to interpret such results without additional information, some possible explanations could be presented. First, the period of high total inflation coincided with a sharp increase in activity which reduced the role of competition among different firms. The factor of competition became more important during the recession, thus increasing the role of price changes on the product level. Second, it could be associated with the sample period, which mostly covers the overheating phase when the probability of price increase could be actually demand driven via aggregate inflation.

Moreover, the comparison of marginal effects in Tables A3 and A4 shows that the importance of inflation is higher for decisions on price rises. Of course, while making such comparisons, we should take into account that price increases in 20032009 were observed 1.6 times more often (see Table 3). However, this fact cannot explain such a big difference between the coefficients in the two models. This conclusion is to some extent in line with Lünnemann and Mathä (2005) who found that accumulated price inflation did not have any significant effect on the probability of price decrease in Luxembourg.

\section{Accumulated changes in demand}

The effect of accumulated changes in demand on the probability of price changes is similar to that of an accumulated inflation: a large improvement in the demand conditions increases the probability of observing positive price change, while a 
pronounced drop in the demand increases the probability of observing price reduction. However, there is an important difference from the effect of accumulated inflation. According to the results in Tables A3 and A4, the demand effect is more important for the probability of price reduction. If sales are taken into account, the effect of an increase of 1 percentage point in accumulated changes of retail trade volumes is rather similar for the probability of both upward and downward price adjustments ( 0.03 and -0.04 percentage point respectively). However, the difference is sizeable if we exclude sales from the analysis: the effect of a 1 percentage point increase in the changes of demand is 0.02 and -0.04 percentage point respectively. These marginal effects are still small compared with those of accumulated inflation; nevertheless, they show the relative importance of demand conditions for permanent price reductions in Latvia.

Time elapsed since the last price change

The probability of price increase is statistically significantly higher for truncations at 9 and 12 months. Meanwhile, the probability of price decrease is statistically significantly larger for truncations at 1, 2, and 12 months. This shows that along with seasonality, prices are truncated after a shorter duration of spells in the case of price decreases. Similar results can be found in Lünnemann and Mathä (2005) and Aucremanne and Dhyne (2005).

Size of the last price change

The size of the last price change does matter for the probability of price increase as well as price decrease. Overall, the sizeable preceding price adjustment reduces the probability of another adjustment in the same direction but increases the probability of price change in the opposite direction. In other words, if the last price increase was large, it increases the probability of price reduction and diminishes the probability of price rise, and vice versa. This effect is still pronounced (although the effects are smaller) for price movements, excluding sales.

Seasonality

The difference in seasonal patterns of the probability of price increase and decrease is showed in Figure 4.

Figure 4

Seasonality in probability of observing price increase and decrease

Including sales

Excluding sales

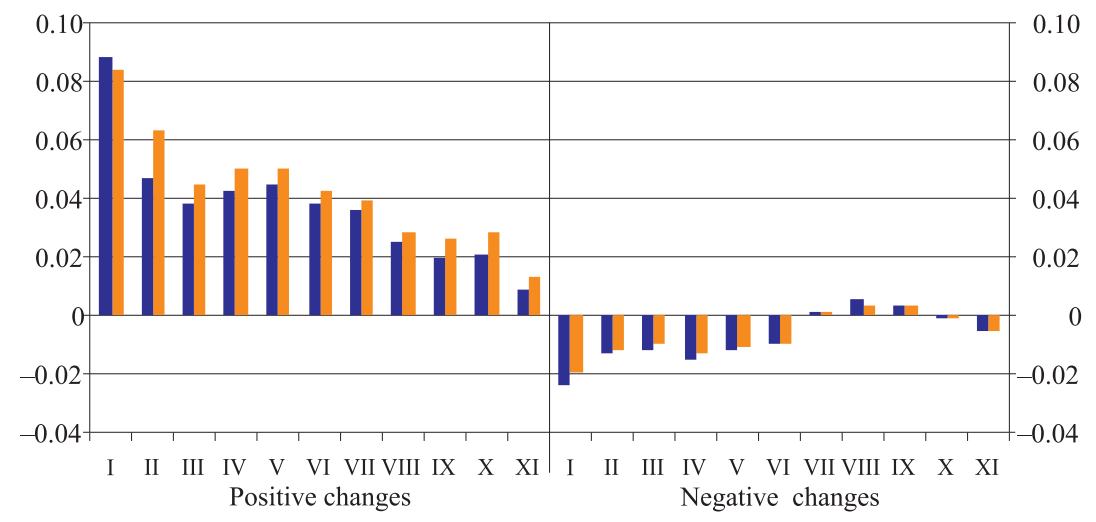

Source: Authors' calculations.

Notes: Seasonal effects show an additional probability of observing price changes compared with December. Figure presents the results from Tables A3 and A4. 
The highest probability of price increase is observed at the beginning of January (or end of December); this can be explained by a Christmas effect. Afterwards, the probability of an upward price revision is gradually diminishing and is the lowest at the end of November or beginning of December. On the contrary, the probability of a price decrease is the lowest in the first part of the year, while a peak of price reductions is observed in August-September.

Attractive prices

The probability to observe a change in attractive prices is lower, regardless of whether we analyse positive or negative price changes. The probability for attractive prices to be increased is 3.1-3.2 percentage points lower and to be decreased 0.3 percentage point lower compared with unattractive prices.

VAT rate change

As expected, an increase of the VAT rate significantly raises the probability of observing price increase, while the reduction of the VAT rate decreases the probability of upward price change. It is interesting to note that only the VAT rate decreases are important for the probability of price reduction, while the VAT rate increases do not affect it.

Year dummy variables

The estimated coefficients before the year dummies for the probability of price increases and decreases are reported in Figure 5.

Figure 5

Year effects for probability of observing price increase and decrease

Including sales

Excluding sales

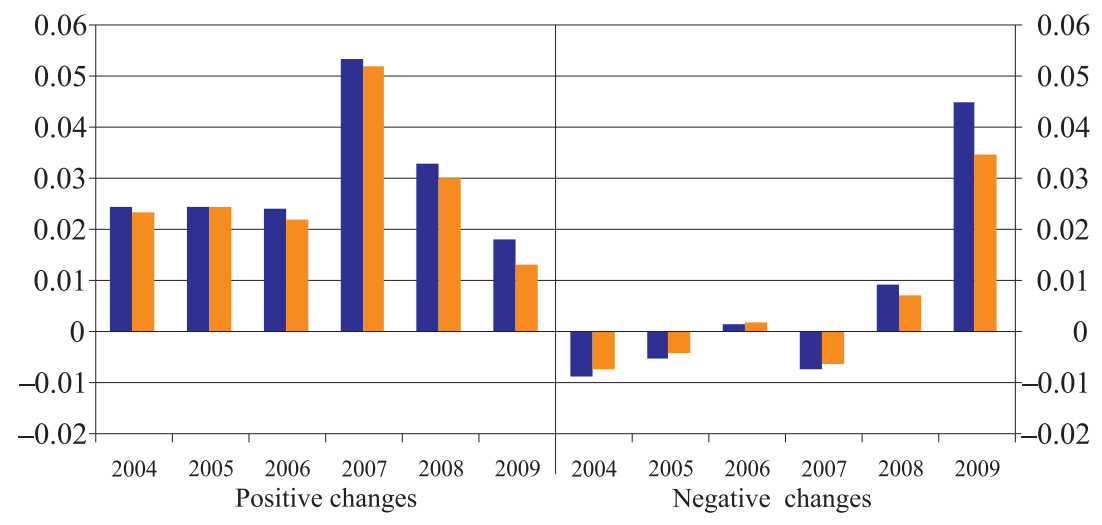

Source: Authors' calculations.

Notes: Year effects show an additional probability of observing price changes compared with 2003. Figure presents the results from Tables A3 and A4.

According to our calculations, with all other explanatory variables fixed, the highest probability of upward price revision was observed in 2007 (by 5.2-5.3 percentage points, compared with 2003), while the highest probability of price decrease - in 2009 (by 3.5-4.5 percentage points, compared with 2003).

There are two possible explanations for such year effects. First, the year dummies can reflect the aggregate demand conditions not captured by the total retail trade volumes, either due to the omission of services sector demand or due to possible nonlinearities. It is indicated by the fact that in 2006-2007 Latvia's economy was significantly overheated, while in 2009 there was a drastic fall in demand which 
roughly corresponds to the shape of Figure 5. However, the demand factor cannot explain the positive and statistically significant coefficients before the dummy variables for 2009 in the equation for price increases, thus indicating some other positive incentives for price increases compared with 2003. Second explanation could be related to the supply side effects which were not included in the model. For example, it could be the effect of a steep energy and food price increase in 2009. Moreover, we should take into account also the increase in several excise tax rates at the beginning of 2009 .

Sectoral dummy variables

We did not find any asymmetry in the sectoral effects - the ranking was very similar to those described in the previous subsection: the most flexible prices are observed in the energy sector, while the highest upward and downward price rigidities were observed for services.

Concluding this part, we would like to summarise the main findings. We found several important differences in the price setting behaviour for cases of price increases and price decreases. The results of the models show that firms decide to increase prices observing overall inflation in Latvia, while they also take into account price changes of particular products when deciding to reduce prices. In addition, changes in inflation are more important for the decision on upward price adjustment. By contrast, changes in demand variables are more important for the decision on price reduction. The probability of price increase is affected by all changes in the VAT rate, while the probability of price reduction depends only on the decrease of VAT rate. There are significant differences in the seasonal pattern of price increases and decreases. Finally, there is evidence on unobserved macroeconomic factors (most likely the demand and supply conditions omitted due to the lack of data or possible nonlinearities) increasing the probability of upward revisions of prices in 2007 and downward revisions in 2009.

\subsection{Explaining probability of sales}

Now we will briefly discuss the probability of observing a temporary price reduction or sales (see Table A5 in Appendix). To do this, we use a binary variable indicating one-month price reduction $\left(Y_{j k t}^{\text {sales }}\right)$ :

$Y_{j k t}^{\text {sales }}=\left\{\begin{array}{ccc}1 & \text { if } & P_{j k t}<P_{j k . t-1} \text { and } P_{j k, t+1}=P_{j k . t-1} \\ 0 & \text { otherwise }\end{array}\right.$

An important conclusion is that the probability of observing a temporary price reduction does not statistically significantly depend on accumulated inflation or demand changes. However, the probability of a temporary price reduction depends on the characteristics of previous price change. First, the probability of observing sales is smaller if some adjustments in the price were made recently (1-4 months ago). Second, the probability of sales increases in the case of large preceding upward revision and decreases in the case of large preceding downward revision (similar to the results in Table A4).

Positive VAT rate changes decrease the probability of sales, while a VAT rate decrease does not affect the probability of temporary price reduction (perhaps leading to more permanent price changes). In contrast to previous results, the 
psychological pricing has no effect on the probability of temporary price reduction. Moreover, there is no seasonal pattern either, as coefficients are significantly different from 0 only for two months, indicating that sales are relatively rare in January and relatively frequent in August.

According to our calculations, the highest probability of temporary price reduction, with all other explanatory variables fixed, was observed in 2008 and 2009. However, the marginal effects are small and are approximately 10 times lower than in Table A4, suggesting that the proportion between short-term and permanent price reductions remained unchanged. The coefficients before the sectoral dummy variables indicate that sales are most often used in the sector of food products, while it is a rarely used strategy for services and nonenergy goods. 


\section{CONCLUSIONS}

The descriptive evidence on price setting behaviour shows that during 2003-2009 Latvia's consumer prices were flexible. The average duration of a price spell was 3.5 months, implying that each month $28.7 \%$ of consumer prices were changed on average . During the investigated period, price increases occurred around 1.6 times more often than price decreases: each month $17.8 \%$ of prices were changed upwards, while only $11.0 \%$ of prices were revised downwards on average. The frequency of price changes was increasing over time. Until the end of 2008, increases in the frequency of price changes were driven by positive price changes, while the frequency of negative price changes was fluctuating around $10 \%$. In the period of economic crisis during 2009, however, the frequency of negative price revisions increased to almost $20 \%$.

To explain the observed pattern in frequency of price changes and to increase the understanding of the price setting behaviour of Latvia's firms, a logit model of the probability of price changes was developed. The set of explanatory variables was rather broad, including variables describing the state of Latvia's economy, characteristics of preceding price adjustment, changes in tax rates, psychological effects, seasonal and sector dummies. The results of the models show that the consumer price formation in Latvia is a combination of both state-dependent and time-dependent behaviour.

An important factor affecting the decision on price adjustment is inflation. Higher inflation increases the probability of observing positive price changes, while lower inflation (or higher deflation) increases the probability of observing price reductions. There are differences in the price setting behaviour for cases of price increases and price decreases, however.

First, the probability of price increase mostly depends on overall accumulated inflation. The probability of price decrease also depends on overall accumulated inflation, but, in contrast to upward price revisions, it also depends on accumulated price changes at the product level. Therefore, firms decide to increase prices observing overall inflation in Latvia, while they also take into account price changes of particular product when deciding to reduce prices. Although it is difficult to interpret such results without additional information, some plausible explanations are possible. First, the period of high total inflation coincided with a sharp increase in activity, which reduced the role of competition among different firms. The factor of competition became more important during the recession, thus increasing the role of price changes at product level. Second, it can be related to the sample period, which mostly covered the overheating phase when the probability of price increase could have actually been demand driven via aggregate inflation.

Second, the changes in inflation are more important for the decision on upward price adjustments, which can be shown when comparing the marginal effects from the equations. A 1-percentage point increase in the total accumulated inflation leads to a 0.82 percentage point higher probability of a price rise. On the other hand, an increase in the total accumulated inflation diminishes the probability of price reduction only by 0.10 percentage point, and an increase in accumulated inflation for individual products diminishes the probability by 0.06 percentage point. 
The effect of changes accumulated in the retail trade volumes on the probability of price changes is similar to that of accumulated inflation: a large improvement in trade increases the probability of observing positive price change, while a pronounced drop in trade volumes increases the probability of observing price reduction. However, this effect is more important for the probability of price reduction, which is especially pronounced for permanent price changes. The marginal effects of retail trade on the probability of price change are small compared with those of accumulated inflation, although they still show relative importance of the demand conditions for permanent price reductions in Latvia.

Not all macroeconomic conditions affecting the frequency of price changes were captured by the model. Even after controlling for all explanatory variables, the probability of price increase in 2007 and price decrease in 2009 was significantly higher than in 2003. First, it could suggest that aggregate demand conditions were not fully captured by the total retail trade volumes used in the model. Another explanation could be related to the supply side effects (e.g. the oil price increase in 2009).

Along with the factors describing the state of Latvia's economy, the probability of price changes depends on the characteristics of preceding price adjustments. A sizeable preceding price adjustment reduces the probability of another adjustment in the same direction, while it increases the probability of price change in the opposite direction.

The time-dependent price setting behaviour is also quite popular among Latvia's firms, as we observed a widespread price truncation in 12 months after the last price change and a strong seasonal pattern. The highest probability of price increase was observed at the beginning of January (or end of December) which could be explained by a Christmas effect. On the contrary, the probability of price decrease was the lowest in the first part of the year, while a peak of price reductions was observed in August and September. We also found evidence of marketing effects, as attractive prices were changed less frequently than unattractive ones. Concerning sectoral heterogeneity, the most flexible prices were observed in the energy sector, while the highest upward and downward price rigidity was displayed by services.

The results of the logit models above lead to several important conclusions about the price setting mechanism in Latvia and have some implication for modelling and policy making. Latvia's firms (or at least a significant share of them) follow the state-dependent pricing strategy. It implies that the models using time-dependent mechanisms a la Calvo are not able to adequately describe the price adjustment process in Latvia, especially in the periods of strong economic fluctuations. In order to capture the changes in price-adjustment process, we need to use models which treat flexibility of prices as endogenous. The fact that frequency of price changes in Latvia depends on inflation, demand and supply conditions could be seen as a prerequisite for faster price adjustment process in the case of distortions in the economy. In the event of economic imbalances, a state-dependent price formation changes flexibility of prices and ensures faster adjustment process towards equilibrium. 


\section{APPENDIX}

\section{Table A1}

\section{Classification of individual products in database}

\begin{tabular}{|c|c|c|c|}
\hline Product group & Product 4-digit group & $\begin{array}{r}\text { Number of } \\
\text { individual } \\
\text { products }\end{array}$ & Product sector \\
\hline $\begin{array}{l}1 \text { Food and non- } \\
\text { alcoholic beverages }\end{array}$ & $\begin{array}{l}\text { 0111 Bread and cereals } \\
0112 \text { Meat } \\
0113 \text { Fish and seafood } \\
0114 \text { Milk, cheese and eggs } \\
0115 \text { Oils and fats } \\
\text { 0116 Fruits } \\
\text { 0117 Vegetables } \\
\text { 0118 Sugar, jam, honey, chocolate and confectionery } \\
\text { 0119 Food products n.e.c. } \\
\text { 0121 Coffee, tea and cocoa } \\
\text { 0122 Mineral waters, soft drinks, fruit and vegetable juices }\end{array}$ & $\begin{array}{r}10 \\
10 \\
2 \\
8 \\
2 \\
3 \\
8 \\
5 \\
5 \\
3 \\
2\end{array}$ & $\begin{array}{l}\text { Processed food } \\
\text { Unprocessed food } \\
\text { Unprocessed food } \\
\text { Unprocessed food } \\
\text { Processed food } \\
\text { Unprocessed food } \\
\text { Unprocessed food } \\
\text { Processed food } \\
\text { Processed food } \\
\text { Processed food } \\
\text { Processed food }\end{array}$ \\
\hline $\begin{array}{l}2 \text { Alcoholic } \\
\text { beverages, tobacco }\end{array}$ & $\begin{array}{l}\text { 0211 Spirits } \\
0212 \text { Wine } \\
0213 \text { Beer } \\
0220 \text { Tobacco }\end{array}$ & $\begin{array}{l}2 \\
1 \\
1 \\
3\end{array}$ & $\begin{array}{l}\text { Non-energy products } \\
\text { Non-energy products } \\
\text { Non-energy products } \\
\text { Non-energy products }\end{array}$ \\
\hline $\begin{array}{l}3 \text { Clothing and } \\
\text { footwear }\end{array}$ & $\begin{array}{l}0312 \text { Garments } \\
0313 \text { Other articles of clothing and clothing accessories } \\
0314 \text { Cleaning, repair and hire of clothing } \\
\text { 0321 Shoes and other footwear } \\
\text { 0322 Repair and hire of footwear }\end{array}$ & $\begin{array}{r}19 \\
2 \\
1 \\
7 \\
1\end{array}$ & $\begin{array}{l}\text { Non-energy products } \\
\text { Non-energy products } \\
\text { Services } \\
\text { Non-energy products } \\
\text { Services }\end{array}$ \\
\hline $\begin{array}{l}\text { 4 Housing, water, } \\
\text { electricity, gas and } \\
\text { other fuels }\end{array}$ & $\begin{array}{l}\text { 0431 Materials for the maintenance and repair of the } \\
\text { dwelling } \\
\text { 0452 Gas } \\
\text { 0454 Solid fuels }\end{array}$ & $\begin{array}{l}4 \\
1 \\
1\end{array}$ & $\begin{array}{l}\text { Non-energy products } \\
\text { Energy } \\
\text { Energy }\end{array}$ \\
\hline $\begin{array}{l}5 \text { Furnishing, } \\
\text { household equipment } \\
\text { and routine } \\
\text { household } \\
\text { maintenance }\end{array}$ & $\begin{array}{l}\text { 0511 Furniture and furnishings } \\
\text { 0520 Household textiles } \\
\text { 0531 Major household appliances } \\
\text { 0532 Small electric household appliances } \\
\text { 0540 Glassware, tableware and household utensils } \\
\text { 0552 Small tools and miscellaneous accessories } \\
\text { 0561 Non-durable household goods } \\
\text { 0562 Domestic services and household services }\end{array}$ & $\begin{array}{l}3 \\
2 \\
1 \\
2 \\
4 \\
5 \\
4 \\
1\end{array}$ & $\begin{array}{l}\text { Non-energy products } \\
\text { Non-energy products } \\
\text { Non-energy products } \\
\text { Non-energy products } \\
\text { Non-energy products } \\
\text { Non-energy products } \\
\text { Non-energy products } \\
\text { Services }\end{array}$ \\
\hline 6 Health & $\begin{array}{l}\text { 0612 Other medical products } \\
0621 \text { Medical services } \\
0622 \text { Dental services } \\
\text { 0623 Paramedical services }\end{array}$ & $\begin{array}{l}2 \\
1 \\
2 \\
2\end{array}$ & $\begin{array}{l}\text { Non-energy products } \\
\text { Services } \\
\text { Services } \\
\text { Services }\end{array}$ \\
\hline 7 Transport & $\begin{array}{l}0713 \text { Bicycles } \\
0721 \text { Spare parts and accessories for personal transport } \\
\text { equipment } \\
0722 \text { Fuels and lubricants for personal transport equipment } \\
0723 \text { Maintenance and repair of personal transport } \\
\text { equipment } \\
0732 \text { Passenger transport by road }\end{array}$ & $\begin{array}{l}1 \\
3\end{array}$ & $\begin{array}{l}\text { Non-energy products } \\
\text { Energy } \\
\text { Services } \\
\text { Services }\end{array}$ \\
\hline 8 Communication & 0820 Telephone and telefax equipment & 1 & Non-energy products \\
\hline $\begin{array}{l}9 \text { Recreation and } \\
\text { culture }\end{array}$ & $\begin{array}{l}0911 \text { Equipment for the reception, recording and } \\
\text { reproduction of sound and pictures } \\
0913 \text { Information processing equipment } \\
0931 \text { Games, toys and hobbies } \\
0932 \text { Equipment for sport, camping and open-air recreation }\end{array}$ & $\begin{array}{l}1 \\
1 \\
1 \\
2\end{array}$ & $\begin{array}{l}\text { Non-energy products } \\
\text { Non-energy products } \\
\text { Non-energy products } \\
\text { Non-energy products }\end{array}$ \\
\hline
\end{tabular}




\begin{tabular}{llrl}
\hline Product group & Product 4-digit group & $\begin{array}{r}\text { Number of } \\
\text { individual } \\
\text { products }\end{array}$ & Product sector \\
\hline & 0933 Gardens, plants and flowers & 2 & Non-energy products \\
& 0934 Pets and related products & 2 & Non-energy products \\
& 0935 Veterinary and other services for pets & 1 & Services \\
& 0941 Recreational and sporting services & 1 & Services \\
& 0942 Cultural services & 3 & Services \\
& 0951 Books & 1 & Non-energy products \\
& 0952 Newspapers and periodicals & 1 & Non-energy products \\
& 0954 Stationery and drawing materials & 3 & Non-energy products \\
\hline 10 Education & 1040 Tertiary education & 1 & Services \\
\hline 11 Restaurants and & 1111 Restaurants, cafes and the like & 7 & Services \\
hotels & 1112 Canteens & 1 & Services \\
& 1120 Accommodation services & 1 & Services \\
\hline 12 Miscellaneous & 1211 Hairdressing salons and personal grooming & & \\
goods and services & establishments & 4 & Services \\
& 1213 Other appliances, articles and products for personal & & \\
& care & 9 & Non-energy products \\
& 1231 Jewellery, clocks and watches & 1 & Non-energy products \\
& 1232 Other personal effects & 3 & Services \\
& 1270 Other services n.e.c. & 1 & Services \\
\hline
\end{tabular}

Sources: CSB and authors' classification. 
Table A2

Panel logit model for probability of price change (2003-2009)

\begin{tabular}{|c|c|c|c|c|}
\hline \multirow[t]{2}{*}{ Variables } & \multicolumn{2}{|c|}{ Including sales } & \multicolumn{2}{|c|}{ Excluding sales } \\
\hline & Coefficients & Marginal effects & Coefficients & Marginal effects \\
\hline Constant & $-0.5390 * *$ & - & $-0.6675^{* *}$ & - \\
\hline$\pi^{\text {product }}$ & 0.0652 & 0.0115 & 0.2273 & 0.0361 \\
\hline$\pi^{\text {group }}$ & $0.1900 * *$ & 0.0335 & $0.1717 * *$ & 0.0273 \\
\hline$\pi^{\text {total }}$ & $5.0240 * *$ & 0.8848 & $4.8460 * *$ & 0.7697 \\
\hline$\overline{v a t^{+}}$ & $49.6922 * *$ & 8.7519 & $55.9388 * *$ & 8.8843 \\
\hline vat & $-7.8111 * *$ & -1.3757 & $-8.3305 * *$ & -1.3231 \\
\hline Trade & $0.3350 * *$ & 0.0590 & $0.2979 * *$ & 0.0473 \\
\hline $\ln (T)$ & $-0.3955 * *$ & -0.0697 & $-0.3501 * *$ & -0.0556 \\
\hline dur 1 & $0.2053 * *$ & 0.0369 & 0.0300 & 0.0048 \\
\hline$d u r 2$ & -0.0625 & -0.0109 & -0.0169 & -0.0027 \\
\hline dur3 & $-0.0863 * *$ & -0.0149 & -0.0547 & -0.0086 \\
\hline dur4 & $-0.1304 * *$ & -0.0223 & $-0.1159 * *$ & -0.0179 \\
\hline dur6 & 0.0225 & 0.0040 & 0.0152 & 0.0024 \\
\hline dur9 & $0.0890 * *$ & 0.0160 & $0.0825 *$ & 0.0134 \\
\hline dur 12 & $0.4215 * *$ & 0.0822 & $0.4362 * *$ & 0.0781 \\
\hline$l d p * l d p d w$ & $-1.6193 * *$ & -0.2852 & $-0.1626 * *$ & -0.0258 \\
\hline$l d p *(1-l d p d w)$ & $-1.0883 * *$ & -0.1917 & $-0.7986 * *$ & -0.1268 \\
\hline atp & $-0.2553 * *$ & -0.0450 & $-0.2775 * *$ & -0.0442 \\
\hline January & $0.2678 * *$ & 0.0500 & $0.2591 * *$ & 0.0439 \\
\hline February & $0.1157 * *$ & 0.0209 & $0.2200 * *$ & 0.0369 \\
\hline March & $0.0896 * *$ & 0.0161 & $0.1353 * *$ & 0.0222 \\
\hline April & $0.0760 * *$ & 0.0136 & $0.1233 * *$ & 0.0202 \\
\hline May & $0.1236 * *$ & 0.0224 & $0.1563 * *$ & 0.0258 \\
\hline June & $0.1184 * *$ & 0.0214 & $0.1421 * *$ & 0.0234 \\
\hline July & $0.2221 * *$ & 0.0411 & $0.2386^{* *}$ & 0.0402 \\
\hline August & $0.2176 * *$ & 0.0402 & $0.2271 * *$ & 0.0381 \\
\hline September & $0.1716^{* *}$ & 0.0314 & $0.2023^{* *}$ & 0.0338 \\
\hline October & $0.1161 * *$ & 0.0210 & $0.1593 * *$ & 0.0263 \\
\hline November & 0.0009 & 0.0002 & 0.0157 & 0.0025 \\
\hline 2004 & $0.0582 * *$ & 0.0104 & $0.0587 * *$ & 0.0094 \\
\hline 2005 & $0.0864 * *$ & 0.0155 & $0.0947 * *$ & 0.0153 \\
\hline 2006 & $0.1399 * *$ & 0.0253 & $0.1347 * *$ & 0.0220 \\
\hline 2007 & $0.2723 * *$ & 0.0503 & $0.2800 * *$ & 0.0470 \\
\hline 2008 & $0.3599 * *$ & 0.0675 & $0.3414 * *$ & 0.0580 \\
\hline 2009 & $0.6512 * *$ & 0.1273 & $0.6009 * *$ & 0.1067 \\
\hline Profood & $-0.8519 * *$ & -0.1315 & $-0.9763 * *$ & -0.1318 \\
\hline Energy & $1.2078 * *$ & 0.2660 & $1.2208 * *$ & 0.2538 \\
\hline Services & $-1.9878 * *$ & -0.2244 & $-1.9715 * *$ & -0.1969 \\
\hline Non-energy & $-0.9820 * *$ & -0.1598 & $-1.0238 * *$ & -0.1492 \\
\hline Number of observations & 374 & & 3743 & \\
\hline Observations with Dep $=0$ & 268 & & 2808 & \\
\hline Observations with Dep $=1$ & 105 & & 934 & \\
\hline
\end{tabular}

Source: Authors' calculations.

Notes: The table reports the coefficients of the logit models as well as marginal effects for sample average values of explanatory variables. $* * *)$ indicate statistical significance at $1 \%(5 \%)$ level. Sales are defined as a temporary price decrease (for one month) with a subsequent price increase to the previous level. 
Table A3

Panel logit model for probability of price increase (2003-2009)

\begin{tabular}{|c|c|c|c|c|}
\hline \multirow[t]{2}{*}{ Variables } & \multicolumn{2}{|c|}{ Including sales } & \multicolumn{2}{|c|}{ Excluding sales } \\
\hline & Coefficients & Marginal effects & Coefficients & Marginal effects \\
\hline Constant & $-1.0190 * *$ & - & $-1.1327^{* *}$ & - \\
\hline$\pi^{\text {product }}$ & 0.0976 & 0.0115 & 0.3071 & 0.0331 \\
\hline$\pi^{\text {group }}$ & $0.3806^{* *}$ & 0.0449 & $0.3388 * *$ & 0.0365 \\
\hline$\pi^{\text {total }}$ & $6.9284 * *$ & 0.8165 & $6.3670 * *$ & 0.6859 \\
\hline$\overline{v a t^{+}}$ & $54.9221 * *$ & 6.4723 & $59.8686 * *$ & 6.4494 \\
\hline vat & $20.7239 * *$ & 2.4422 & $18.5755^{*}$ & 2.0011 \\
\hline Trade & $0.2575 * *$ & 0.0303 & 0.1414 & 0.0152 \\
\hline $\ln (T)$ & $-0.7439 * *$ & -0.0877 & $-0.6445 * *$ & -0.0694 \\
\hline dur 1 & $-0.3380 * *$ & -0.0381 & $-0.5726 * *$ & -0.0572 \\
\hline$d u r 2$ & $-0.4163 * *$ & -0.0442 & $-0.3454 * *$ & -0.0340 \\
\hline dur3 & $-0.2812 * *$ & -0.0306 & $-0.2331 * *$ & -0.0234 \\
\hline dur4 & $-0.2442 * *$ & -0.0267 & $-0.2159 * *$ & -0.0217 \\
\hline dur6 & 0.0410 & 0.0049 & 0.0414 & 0.0045 \\
\hline dur9 & $0.1258 * *$ & 0.0155 & $0.1110 * *$ & 0.0124 \\
\hline dur12 & $0.4893 * *$ & 0.0682 & $0.4613 * *$ & 0.0586 \\
\hline$l d p * l d p d w$ & $-2.1357 * *$ & -0.2517 & $-0.7303 * *$ & -0.0787 \\
\hline$l d p *(1-l d p d w)$ & $-2.2235 * *$ & -0.2620 & $-1.4335 * *$ & -0.1544 \\
\hline atp & $-0.2626 * *$ & -0.0310 & $-0.2927 * *$ & -0.0316 \\
\hline January & $0.6253 * *$ & 0.0889 & $0.6365 * *$ & 0.0837 \\
\hline February & $0.3600 * *$ & 0.0473 & $0.5065^{* *}$ & 0.0640 \\
\hline March & $0.2947 * *$ & 0.0379 & $0.3686 * *$ & 0.0446 \\
\hline April & $0.3283 * *$ & 0.0427 & $0.4091 * *$ & 0.0501 \\
\hline May & $0.3465 * *$ & 0.0453 & $0.4114 * *$ & 0.0503 \\
\hline June & $0.3026^{* *}$ & 0.0390 & $0.3588 * *$ & 0.0432 \\
\hline July & $0.2815^{* *}$ & 0.0361 & $0.3284 * *$ & 0.0392 \\
\hline August & $0.1975 * *$ & 0.0247 & $0.2413 * *$ & 0.0280 \\
\hline September & $0.1598 * *$ & 0.0198 & $0.2229 * *$ & 0.0257 \\
\hline October & $0.1682 * *$ & 0.0208 & $0.2447 * *$ & 0.0284 \\
\hline November & $0.0783 * *$ & 0.0094 & $0.1165 * *$ & 0.0130 \\
\hline 2004 & $0.1983^{* *}$ & 0.0246 & $0.2041 * *$ & 0.0233 \\
\hline 2005 & $0.1966 * *$ & 0.0244 & $0.2160 * *$ & 0.0246 \\
\hline 2006 & $0.1941 * *$ & 0.0240 & $0.1943 * *$ & 0.0220 \\
\hline 2007 & $0.4108 * *$ & 0.0535 & $0.4333^{* *}$ & 0.0521 \\
\hline 2008 & $0.2622 * *$ & 0.0329 & $0.2634 * *$ & 0.0303 \\
\hline 2009 & $0.1481 * *$ & 0.0181 & $0.1180 * *$ & 0.0131 \\
\hline Profood & $-0.4418 * *$ & -0.0478 & $-0.6240 * *$ & -0.0594 \\
\hline Energy & $0.7394 * *$ & 0.1105 & $0.8434 * *$ & 0.1205 \\
\hline Services & $-1.0920 * *$ & -0.0958 & $-1.2633 * *$ & -0.0962 \\
\hline Non-energy & $-0.5127 * *$ & -0.0575 & $-0.6486 * *$ & -0.0656 \\
\hline Number of observations & 374 & & 3743 & \\
\hline Observations with Dep $=0$ & 308 & & 3154 & \\
\hline Observations with Dep $=1$ & 65 & & 588 & \\
\hline
\end{tabular}

Source: Authors' calculations.

Notes: The table reports the coefficients of the logit models as well as marginal effects for sample average values of explanatory variables. $* * *)$ indicate statistical significance at $1 \%(5 \%)$ level. Sales are defined as a temporary price decrease (for one month) with a subsequent price increase to the previous level. 
Table A4

Panel logit model for probability of price decrease (2003-2009)

\begin{tabular}{|c|c|c|c|c|}
\hline \multirow[t]{2}{*}{ Variables } & \multicolumn{2}{|c|}{ Including sales } & \multicolumn{2}{|c|}{ Excluding sales } \\
\hline & Coefficients & Marginal effects & Coefficients & Marginal effects \\
\hline Constant & $-1.7218 * *$ & - & $-2.1295 * *$ & - \\
\hline$\pi^{\text {product }}$ & $-1.1035 * *$ & -0.0622 & $-1.2719 * *$ & -0.0588 \\
\hline$\pi^{\text {group }}$ & -0.0128 & -0.0007 & -0.0529 & -0.0024 \\
\hline$\pi^{\text {total }}$ & $-1.9788 * *$ & -0.1115 & $-2.2344 * *$ & -0.1034 \\
\hline$\overline{v a t^{+}}$ & -3.7770 & -0.2129 & 1.9362 & 0.0896 \\
\hline vat & $-17.7833 * *$ & -1.0022 & $-18.3024 * *$ & -0.8468 \\
\hline Trade & $-0.6257 * *$ & -0.0353 & $-0.9080 * *$ & -0.0420 \\
\hline $\ln (T)$ & $-0.1861 * *$ & -0.0105 & -0.0850 & -0.0039 \\
\hline dur 1 & $0.2974 * *$ & 0.0176 & $0.6321 * *$ & 0.0328 \\
\hline$d u r 2$ & $0.2315 * *$ & 0.0140 & $0.4060 * *$ & 0.0214 \\
\hline dur3 & 0.0870 & 0.0051 & $0.1981 * *$ & 0.0098 \\
\hline dur4 & 0.0032 & 0.0002 & 0.0601 & 0.0028 \\
\hline dur6 & -0.0216 & -0.0012 & -0.0537 & -0.0024 \\
\hline dur9 & 0.0319 & 0.0018 & 0.0068 & 0.0003 \\
\hline dur 12 & $0.1888^{*}$ & 0.0115 & $0.3064 * *$ & 0.0162 \\
\hline$l d p * l d p d w$ & $0.8653 * *$ & 0.0488 & $0.6167 * *$ & 0.0285 \\
\hline$l d p *(1-l d p d w)$ & $0.4721 * *$ & 0.0266 & $0.1972 * *$ & 0.0091 \\
\hline atp & $-0.0529 * *$ & -0.0030 & $-0.0554 * *$ & -0.0026 \\
\hline January & $-0.5144 * *$ & -0.0240 & $-0.5426^{* *}$ & -0.0205 \\
\hline February & $-0.2573 * *$ & -0.0132 & $-0.2812 * *$ & -0.0117 \\
\hline March & $-0.2238 * *$ & -0.0116 & $-0.2349 * *$ & -0.0100 \\
\hline April & $-0.2945 * *$ & -0.0149 & $-0.3213 * *$ & -0.0132 \\
\hline May & $-0.2336 * *$ & -0.0121 & $-0.2573 * *$ & -0.0108 \\
\hline June & $-0.1991 * *$ & -0.0104 & $-0.2252 * *$ & -0.0096 \\
\hline July & 0.0136 & 0.0008 & 0.0058 & 0.0003 \\
\hline August & $0.0865 * *$ & 0.0050 & $0.0629 *$ & 0.0030 \\
\hline September & $0.0638^{*}$ & 0.0037 & $0.0690 *$ & 0.0033 \\
\hline October & -0.0197 & -0.0011 & -0.0285 & -0.0013 \\
\hline November & $-0.0910 * *$ & -0.0050 & $-0.1151 * *$ & -0.0051 \\
\hline 2004 & $-0.1644 * *$ & -0.0088 & $-0.1633 * *$ & -0.0072 \\
\hline 2005 & $-0.0973 * *$ & -0.0053 & $-0.0948 * *$ & -0.0043 \\
\hline 2006 & 0.0256 & 0.0015 & 0.0409 & 0.0019 \\
\hline 2007 & $-0.1336 * *$ & -0.0072 & $-0.1446 * *$ & -0.0064 \\
\hline 2008 & $0.1584 * *$ & 0.0094 & $0.1462 * *$ & 0.0071 \\
\hline 2009 & $0.6565 * *$ & 0.0451 & $0.6215^{* *}$ & 0.0349 \\
\hline Profood & $-0.7392 * *$ & -0.0354 & $-1.1024 * *$ & -0.0386 \\
\hline Energy & $0.5041 * *$ & 0.0350 & $0.7684 * *$ & 0.0474 \\
\hline Services & $-2.4912 * *$ & -0.0723 & $-2.4612 * *$ & -0.0560 \\
\hline Non-energy & $-0.8725 * *$ & -0.0450 & $-1.1059 * *$ & -0.0440 \\
\hline Number of observations & 374 & & 3743 & \\
\hline Observations with Dep $=0$ & 334 & & 3397 & \\
\hline Observations with Dep $=1$ & 40 & & 345 & \\
\hline
\end{tabular}

Source: Authors' calculations.

Notes: The table reports the coefficients of the logit models as well as marginal effects for sample average values of explanatory variables. $* *(*)$ indicate statistical significance at $1 \%(5 \%)$ level. Sales are defined as a temporary price decrease (for one month) with a subsequent price increase to the previous level. 
Table A5

Panel logit model for probability of sales (2003-2009)

\begin{tabular}{|c|c|c|}
\hline Variables & Coefficients & Marginal effects \\
\hline Constant & $-3.3125^{* *}$ & \\
\hline$\overline{\pi^{\text {product }}}$ & -0.3152 & -0.0021 \\
\hline$\pi^{\text {group }}$ & 0.1321 & 0.0009 \\
\hline$\pi^{\text {total }}$ & -2.3100 & -0.0151 \\
\hline $\mathrm{vat}^{+}$ & $-66.5102 * *$ & -0.4336 \\
\hline vat & -5.2894 & -0.0345 \\
\hline Trade & 0.4927 & 0.0032 \\
\hline $\ln (T)$ & $-0.6819 * *$ & -0.0044 \\
\hline dur1 & $-1.1488 * *$ & -0.0064 \\
\hline$d u r 2$ & $-0.4279 * *$ & -0.0024 \\
\hline$d u r 3$ & $-0.3093 * *$ & -0.0018 \\
\hline dur4 & $-0.1911^{*}$ & -0.0012 \\
\hline dur6 & 0.0874 & 0.0006 \\
\hline dur9 & 0.1083 & 0.0007 \\
\hline dur 12 & -0.4205 & -0.0023 \\
\hline$l d p * l d p d w$ & $2.8900^{* *}$ & 0.0188 \\
\hline$l d p *(1-l d p d w)$ & $1.5283^{* *}$ & 0.0100 \\
\hline atp & -0.0114 & -0.0001 \\
\hline$\overline{\text { January }}$ & $-0.1813^{*}$ & -0.0011 \\
\hline February & -0.0412 & -0.0003 \\
\hline March & -0.0849 & -0.0005 \\
\hline April & -0.0602 & -0.0004 \\
\hline May & -0.0382 & -0.0002 \\
\hline June & -0.0077 & -0.0001 \\
\hline July & 0.0430 & 0.0003 \\
\hline August & $0.1274 *$ & 0.0009 \\
\hline September & -0.0299 & -0.0002 \\
\hline October & 0.0164 & 0.0001 \\
\hline November & 0.0466 & 0.0003 \\
\hline 2004 & -0.1195 & -0.0007 \\
\hline 2005 & -0.0879 & -0.0006 \\
\hline 2006 & -0.0545 & -0.0003 \\
\hline 2007 & -0.0486 & -0.0003 \\
\hline 2008 & $0.1460 *$ & 0.0010 \\
\hline 2009 & $0.5385^{* *}$ & 0.0042 \\
\hline Profood & 0.0357 & 0.0002 \\
\hline Energy & -0.1123 & -0.0007 \\
\hline Services & $-3.1967 * *$ & -0.0092 \\
\hline Non-energy & $-0.3910^{* *}$ & -0.0024 \\
\hline Number of observations & 3743 & \\
\hline Observations with Dep $=0$ & 3687 & \\
\hline Observations with Dep $=1$ & 55 & \\
\hline
\end{tabular}

Source: Authors' calculations.

Notes: The table reports the coefficients of the logit models as well as marginal effects for sample average values of explanatory variables. $* * *)$ indicate statistical significance at $1 \%(5 \%)$ level. Sales are defined as a temporary price decrease (for one month) with a subsequent price increase to the previous level. 


\section{BIBLIOGRAPHY}

1 AUCREMANNE, Luc, DHYNE, Emmanuel (2005) - Time-Dependent versus State-Dependent Pricing: a Panel Data Approach to the Determinants of Belgian Consumer Price Changes. European Central Bank Working Paper Series, No. 462, March.

2 BAUDRY, Laurent, LE BIHAN, Hervé, SEVESTRE, Patrick, TARRIEU, Sylvie (2007) - What do Thirteen Million Price Records have to Say about Consumer Price Rigidity? Oxford Bulletin of Economics and Statistics, vol. 69, issue 2, April, pp. 139-183.

3 BAUMGARTNER, Josef, GLATZER, Ernst, RUMLER, Fabio, STIGLBAUER, Alfred (2005) - How Frequently do Consumer Prices Change in Austria? Evidence from Micro CPI Data. European Central Bank Working Paper Series, No. 523, September.

4 BEN̦KOVSKIS, Konstantīns, KALNBĒRZIN̦A, Krista, FADEJEVA, Ludmila (2010)- Price Setting Behaviour in Latvia: Descriptive Evidence from CPI Microdata. Latvijas Banka Discussion Paper, No. 1.

5 CALVO, Guillermo A. (1983) - Staggered Prices in a Utility-Maximizing Framework. Journal of Monetary Economics, vol. 12, issue 3, September, pp. 383398.

6 CAPLIN, Andrew S., SPULBER, Daniel F. (1987) - Menu Costs and the Neutrality of Money. Quarterly Journal of Economics, vol. 102, issue 4, November, pp. 703-725.

7 CECCHETTI, Stephen G. (1986) - The Frequency of Price Adjustment: A Study of the Newsstand Prices of Magazines. Journal of Econometrics, vol. 31, issue 3, April, pp. 255-274.

8 DOTSEY, Michael, KING, Robert G., WOLMAN, Alexander L. (1999) State-Dependent Pricing and the General Equilibrium Dynamics of Money and Output. Quarterly Journal of Economics, vol. 114, issue 2, May, pp. 655-690.

9 LÜNNEMANN, Patrick, MATHÄ, Thomas Y.(2005) - Consumer Price Behaviour in Luxembourg: Evidence from Micro CPI Data. European Central Bank Working Paper Series, No. 541, November.

10 MACKOWIAK, Bartosz, WIEDERHOLT, Mirko (2009) - Optimal Sticky Prices under Rational Inattention. American Economic Review, vol. 99, issue 3, June, pp. 769-803.

11 ROTEMBERG, Julio J. (1982a) - Monopolistic Price Adjustment and Aggregate Output. Review of Economic Studies, vol. 49, No. 4, October, pp. 517531.

12 ROTEMBERG, Julio J. (1982b) - Sticky Prices in the United States. Journal of Political Economy, vol. 90, No. 6, December, pp. 1187-1211.

13 TAYLOR, John B. (1980) - Aggregate Dynamics and Staggered Contracts. Journal of Political Economy, vol. 88, No. 1, February, pp. 1-23. 